\title{
Measuring Self-Regulation in Self-Paced Open and Distance Learning Environments
}

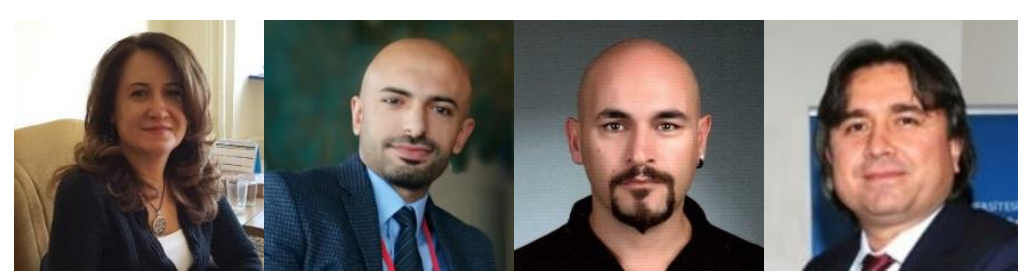

Serpil Kocdar', Abdulkadir Karadeniz', Aras Bozkurt'1,2, and Koksal Buyuk ${ }^{1}$ ${ }^{1}$ Anadolu University, 2University of South Africa

\begin{abstract}
Previous studies have described many scales for measuring self-regulation; however, no scale has been developed specifically for self-paced open and distance learning environments. Therefore, the aim of this study is to develop a scale for determining the self-regulated learning skills of distance learners in selfpaced open and distance learning courses. Participants of this study were 1279 distance learners who were part of self-paced distance learning courses in a public open and distance teaching university in Turkey. The items of the scale were prepared based on the literature review, expert opinions, and learner questionnaires. The items of the scale were reduced from 62 to 30 after expert opinions and validity and reliability analyses. For the validity of the scale, the exploratory and confirmatory factor analyses were conducted. The total variance was found to be $58.204 \%$. The Cronbach's alpha coefficient calculated for the reliability of the scale was found to be .937. Five factors composed of goal setting, help seeking, selfstudy strategies, managing physical environment, and effort regulation emerged in the 30-item scale. Thus, it was concluded that the scale has a high validity and reliability. This scale is intended to help teachers and instructional designers in developing strategies that will enable learners to either enhance their existing self-regulated learning skills or help them to acquire new skills in self-paced open and distance learning environments.
\end{abstract}

Keywords: self-regulated learning, self-paced open and distance learning, flexible learning, independent learning, autonomous learners

\section{Introduction}

Learner-paced distance or e-learning courses provide learners with flexible and independent learning experiences, as they can start their courses at any time during the year, and complete them at their own pace (Anderson, Annand, \& Wark, 2005). Distance learners can study and learn at any time and place they want; however, they are responsible for planning, managing, and assessing their learning processes 
(Moore \& Kearsley, 2012). These learners should know ways to achieve success and independently develop their skills (Dabbagh \& Kitsantas, 2009; Wilson, 1997). The fact that distance learning is more flexible, learner-centered, and autonomous than face-to-face learning requires learners to be self-regulated and use their self-regulated learning skills more frequently (Kuo, Walker, Schroder, \& Belland, 2014). Previous studies support the theory that self-regulated learners are more successful in distance learning (Kuo et al., 2014; Yukselturk \& Bulut, 2007). Conversely, studies have also shown that most distance learners have difficulties in managing their learning processes, and, are thus, subject to failure (Barnard-Brak, Lan, \& Paton, 2010; Lehmann, Hähnlein, \& Ifenthaler, 2014). Failure frequently occurs during self-paced open and distance learning as the learners study at their own pace. For instance, most of the MOOCs are selfpaced, and the success of the MOOCs mostly rely on the learners being self-regulated. Furthermore, the lack of self-regulated skills results in high dropout and low retention rates (Milligan, Littlejohn, \& Margaryan, 2013; Littlejohn, Hood, Milligan, \& Mustain, 2016).

Identification of self-regulated learning skills is important as these are learnable skills, and instructors can help learners acquire these skills (Azevedo \& Cromley, 2004; Dabbagh \& Kitsantas, 2012; Koçdar, 2015). There are scales in the literature that guide teachers to identify the self-regulated learning skills of learners learning either in face-to-face (Brown, Miller, \& Lawendowski, 1999; Pintrich, Smith, Garcia, \& McKeachie, 1991; Weinstein, Palmer, \& Acee, 2016) or online (Barnard, Lan, To, Paton, \& Lai, 2009). Although these scales serve for face-to-face or online courses, they are not based on learner-paced or selfstudy. Therefore, they primarily focus on classroom activities in structured learning environments involving schedules that do not fit well into a self-paced learning environment. Consequently, it is essential to determine the self-regulated learning skills that enable learners to regulate and manage their own learning processes in learner-paced open and distance learning environments. Determining these skills will aid the teachers and instructional designers in developing new strategies, which will either enhance the learners' skills in self-regulated learning or help them acquire skills crucial for a successful distance learning experience and becoming lifelong learners. Based on the above deliberations, the present study aimed to develop a scale to help identify self-regulation in self-paced open and distance learning environments.

\section{Self-Regulated Learning}

The concept of self-regulated learning, which emphasizes responsibilities of learners in their own learning processes and autonomy was first noted in the 1980 os (Koçdar, 2015; Whipp \& Chiarelli, 2004). According to Zimmerman and Schunk (1989), self-regulation is the ability of learners to effectively engage in their own learning processes metacognitively, motivationally, and behaviorally. Pintrich (2000) defined selfregulated learning as "an active and constructivist process whereby learners attempt to monitor, regulate, and control their cognition, motivation and behaviors after setting goals for their learning, are guided and restricted by their own goals and the learning environment they are in" (p. 453). Therefore, self-regulation is a set of strategies that significantly affect learning (Whipp \& Chiarelli, 2004). Self-regulation includes setting goals, using effective strategies for regulating learning, coding and repeating information, monitoring performance, asking for help when needed, and having confidence in one's own skills (Dabbagh \& Kitsantas, 2005; Zimmerman \& Risemberg, 1997). A learner who can self-regulate is organized, does careful planning, and makes keen observations and assessments (Butler \& Winne, 1995).

The argument that social context is important in self-regulated learning has been dominant for 20 years (Hadwin, Oshige, Gres, \& Winne, 2010). Social context plays an important role in self-regulated learning (Zimmerman, 2000). Instructors or peers are external factors who become models to guide learners in self-regulation activities and provide feedback (Hadwin et al., 2010). They can support their beliefs such 
as self-efficacy and goal centeredness, and help learners deal with their feelings such as anxiety and fear. These models can also help learners understand the correlation between their social and physical environments. From a social cognitive perspective, social context offers important opportunities that can support the self-regulated learning process. These opportunities include practices that include guiding elements, the control of learner, decreasing instructional support, and effective feedbacks (Hadwin et al., 2010; Zimmerman, 2000). Because of the social processes, learners can develop their competencies to meet challenges, for content and context. Consequently they become self-regulated learners (Hadwin et al., 2010).

\section{Self-Paced Learning}

Naidu (2008) defines self-paced learning as "a mode of learning that enables individuals to study online or with the help of portable technologies in their own time, at their own pace, and from their own place" (p. 260). Self or learner paced distance and e-learning courses at universities are based on increased learner independence and flexibility, as learners can start their courses at any time during the year, and complete them at their own pace (Anderson et al., 2005). Moreover, there are self-paced distance education courses with specific start and end dates such as the Open University of UK or Anadolu University courses. This type of flexible learning is also known as learner-paced, self-study or independent study (Anderson et al., 2005). Independent study is closely related to self-directed learning and self-regulation (Garrison, 2000). Bergamin, Werlen, Siegenthaler, and Ziska (2012) state that flexible learning requires learners to possess skills of autonomous and self-regulated learning already to effectively engage in learning activities that are open regarding time, pace, and content. Thus, selfregulated learning skills are critical for success in the self-paced distance and online learning environments (Barnard et al., 2009; Bergamin et al., 2012; Kaufmann, 2004; Koçdar, 2015). Table 1 shows the differences between instructor-paced and self-paced courses.

Table 1

\section{Instructor-Paced vs. Self-Paced Courses}

\begin{tabular}{|c|c|}
\hline Instructor-paced courses & Self-paced courses \\
\hline $\begin{array}{l}\text { - Structured learning environment that is led } \\
\text { by a faculty member or instructor, who sets } \\
\text { the pace for the class. } \\
\text { - } \quad \text { Follow a set schedule. } \\
\text { - } \text { spurse materials become available at } \\
\text { dates for assignmes as the course progresses due } \\
\text { for exams. } \\
\text { - Immediate feedback by the instructors. } \\
\text { May not be flexible regarding time and/or } \\
\text { place. }\end{array}$ & $\begin{array}{l}\text { - Allow students to take courses at their own } \\
\text { pace. } \\
\text { - Do not follow a set schedule. } \\
\text { - All the course materials become available } \\
\text { when the course begins. } \\
\text { May have no start or due dates for exams } \\
\text { and assignments. } \\
\text { - Delayed feedback by the instructors or } \\
\text { tutors. } \\
\text { - Flexible regarding time and/or place. }\end{array}$ \\
\hline
\end{tabular}

*Adapted from "Differences between instructor- and self-paced courses," by edX, 2018 (http://edx.readthedocs.io/projects/edx-guide-forstudents/en/latest/SFD_self_paced.html) Copyright 2018 by edX.

\section{Related Studies}

Researchers have developed several scales to determine the self-regulation skills of university students. The most commonly used scale is the Motivated Strategies for Learning Questionnaire, (MSLQ) which 
was developed by Pintrich et al. (1991). The Self-Regulation Questionnaire (SRQ) (Brown et al., 1999) and the Learning and Study Strategies Inventory (Weinstein et al., 2016) are the other scales used to identify the supporting self-regulated learning skills, but these scales were developed for face-to-face learning. Therefore, these scales are not useful in learner-paced open and distance learning environments. In addition to these scales, the Online Self-Regulated Learning Questionnaire (OSLQ), which can be used in online settings, was developed by Barnard et al. (2009). However, OSLQ is also not appropriate for the learner-paced open and distance learning experience and is used mostly in cohort-based online learning settings. This indicates the need for a self-regulated learning skills scale for learner-paced distance learning practices. Therefore, the aim of this study was to develop a scale for determining a learner's selfregulated learning skills, which are necessary for success in learner-paced open and distance learning.

\section{Method}

A scale is a tool, mechanism, or instrument by which individuals are distinguished from one another based on the variables of interest in a meaningful way (Sekaran \& Bougie, 2016). The primary goal of scale development is to create a valid measure of an underlying construct (Clark \& Watson, 1995). Thus, this study employed a seven-stage process to develop a scale for measuring the self-regulation skills of learners who continue their education in learner-paced open and distance learning environments.

\section{Setting Item Pool}

A literature review regarding the topic was conducted first, and similar studies were determined (Barnard et al., 2009; Brown et al., 1999; Pintrich et al., 1991; Weinstein et al., 2016). The reviewed studies were used and the opinions of researchers and field experts were noted. Moreover, an online questionnaire form consisting of open-ended questions was sent to distance learners. The questionnaire was answered by 17 learners. A pool consisting of 62 items was generated based on the analysis of previous studies and the responses obtained from the questionnaire that was sent to learners. The item pool was designed including both positive and negative items.

\section{Developing the Draft Scale}

Items were prepared using a 5-point Likert type scale including "strongly agree," "agree," "slightly agree," "disagree," and "strongly disagree." In positive items, the scores of "strongly agree," "agree," "slightly agree," "disagree," and "strongly disagree" ranged from 5 to 1, respectively, and the scores were reversed in the negative items.

\section{Ensuring Content Validity}

A commonly used method for determining content validity that represents the quantitative and qualitative competence of items is to consult experts (Buyukozturk, 2009). In this regard, the 62-item pool was presented to obtain expert opinions, and its content validity was tested. The 62 -item scale was presented to seven experts for evaluation in a way to indicate seven different dimensions, which were determined based on previous studies. The experts were selected from researchers having a $\mathrm{PhD}$ and working in the field of open and distance learning. After the evaluation of experts, the item pool was reduced to 55 , and the suggested adjustments were made.

\section{Implementation Stage}


The participants were distance learning students enrolled in self-paced courses at Anadolu University, which is a public, dual mode, open and distance teaching university in Turkey and is considered as a mega university (Daniel, 1996) with more than 2 million students. The developed draft scale was published in the eCampus System that can be accessed by all students enrolled in more than 60 different undergraduate programs in the open education system of the university. The scale was designed in a way that enabled each student to answer it only once. It remained in the system for 10 days, and 1, 279 students responded to the scale. As seen in Table 2, $57 \%(\mathrm{n}=729)$ of the participants were male, whereas $43 \%$ $(n=550)$ of them were female. The age of the participants varied significantly ranging from 16 to 69 .

Table 2

Demographics of the Participants

\begin{tabular}{|c|c|c|c|c|c|c|c|c|c|c|c|}
\hline & & \multicolumn{9}{|c|}{ Age category } & \multirow[b]{2}{*}{ Total } \\
\hline & & $\begin{array}{l}\text { in } \\
\vdots \\
b \\
-1\end{array}$ & $\begin{array}{l}\text { Nิ } \\
\text { N } \\
\text { Nิ }\end{array}$ & $\begin{array}{l}\text { कి } \\
1 \\
\infty \\
\text { N }\end{array}$ & $\begin{array}{l}\text { के } \\
\dot{1} \\
\text { mे }\end{array}$ & \begin{tabular}{l}
10 \\
\multirow{1}{1}{} \\
$\stackrel{+}{+}$
\end{tabular} & $\begin{array}{l}\overrightarrow{1} \\
\hat{b} \\
+\end{array}$ & $\begin{array}{l}\hat{1} \\
\hat{1} \\
\text { ஸ̂. }\end{array}$ & $\begin{array}{l}\mathscr{0} \\
1 \\
1 \\
1 \\
10\end{array}$ & $\begin{array}{l}0 \\
0 \\
1 \\
0\end{array}$ & \\
\hline \multirow[t]{2}{*}{ Gender } & Male & 53 & 180 & 149 & 130 & 107 & 69 & 30 & 9 & 2 & 729 \\
\hline & Female & 32 & 133 & 95 & 103 & 91 & 61 & 30 & 2 & 3 & 550 \\
\hline \multicolumn{2}{|c|}{ Total } & 85 & 313 & 244 & 233 & 198 & 130 & 60 & 11 & 5 & 1279 \\
\hline
\end{tabular}

\section{Item Analysis and Construct Validity}

First, an item analysis was conducted by using data obtained from the implementation, and then the correlation between the scores obtained from each item and the total scores obtained from the entire scale were calculated. The items whose item-test score correlations were below .30 were excluded. Exploratory Factor Analysis was conducted on the other items. The number of factors was limited to seven because the literature indicated it to be the maximum, and seven different dimensions were used to establish the item pool. Subsequently, the Varimax rotation technique was applied. The decision about whether an item was appropriate for a factor was based on having the factor loading at a minimum of .40. It was also based on having at least a .10-point difference between the factor loading in the closest factor (Buyukozturk, 2009; Tavsancil, 2014). After the Exploratory Factor Analysis, the Confirmatory Factor Analysis was implemented and the factor structure was confirmed.

\section{Testing the Reliability}

To test the reliability of the scale, the item-total test score correlation and the Cronbach's alpha reliability coefficient value of items were calculated and examined. The Cronbach's alpha reliability coefficient value is a measure of the internal consistency between the test scores of a scale. The values above 0.70 were accepted as adequate for the test reliability. The item-total test score correlation is used to explain the 
relationship between the score of each item and the total score of all test items. The item-total test score correlation was found to be high and positive indicating that the scale has an internal consistency (Buyukozturk, 2009).

\section{Finalization of the Scale}

The final version of the scale included five factors and 30 items (Appendix).

\section{Results}

In accordance with the analyses, the obtained results are explained in four different steps:

\section{Conducting Item Analysis of the Data}

First, the descriptive statistics of the scale of self-regulation skills were examined within the context of item analysis. Because of the implementation of scale, the lowest and the highest scores were found to be 67 and 268, respectively. In this case, the range was 201. This value involves the adequate part of the expected range. The mean score of the scale was found to be 171.78 , and its standard deviation was found to be 33.737. The skewness and kurtosis coefficients calculated for the distribution were -0.157 and 0.152, respectively indicating that the data were normally distributed.

The Cronbach's alpha coefficient calculated for the reliability of the scale after the implementation was found to be .937. To determine the extent to which the scale items measured similar behaviors, the itemtotal correlation was examined, and the items below .30 - 7 items (12th, 14th, 18th, 35th, 36th, 46th, 55th items) - were excluded from the scale. The independent samples t-test was used to find the significance (p) of difference between the item scores of the top $27 \%$ and the bottom $27 \%$. It was used based on the study groups to determine the adequacy of each item of the scale in distinguishing individuals. No item was excluded from the scale before the factor analysis, because no items were found with a p value higher than 0.05 .

\section{Assessing the Suitability of Data for the Exploratory Factor Analysis}

The Kaiser-Meyer-Olkin (KMO) coefficient and Bartlett's test can be used to determine whether the data are suitable for the factor analysis. Thus, it is expected that the results of the Bartlett's test were found to be significant and the KMO value higher than 0.50. The results of Bartlett's test and the KMO value are presented in Table 3 . 
Table 3

Assessing the Suitability of Data for the Exploratory Factor Analysis

\begin{tabular}{|l|c|c|}
\hline \multicolumn{2}{|c|}{ Kaiser-Meyer-Olkin (KMO) } & .953 \\
\hline \multirow{3}{*}{ Bartlett's test } & Chi-square value & 33228.995 \\
\cline { 2 - 3 } & Sd & 1128 \\
\cline { 2 - 3 } & $\mathrm{p}<0.05$ & .000 \\
\hline
\end{tabular}

As can be seen from Table 3, the KMO coefficient and Bartlett's Sphericity value of 48 items which passed the reliability test were found to be .953 and .ooo, respectively. The KMO coefficient showed that the sample size was close to perfect, and the Bartlett test result indicated that the obtained data set was suitable for Exploratory Factor Analysis. A significance value lower than 0.05 indicated that the relationship between variables was adequate in conducting factor analysis.

\section{Examining the Construct Validity of the Draft Scale}

As a result of the Varimax rotation, items were found to explain $58.204 \%$ of the total variance as seven factors. It was noted that the lower bound of item factor loadings was 0.40 , and the difference between the two factor loadings of the same item was .10 at a minimum. Items which were not suitable for this criterion (26th, 33rd, 40th, 41st and 54th items) were excluded from the scale. The reliability of 21 items divided into seven factors was examined. The Cronbach's alpha coefficients of the 1st, 2nd, 3rd, 4th, 5th, 6th, and 7 th factors were found to be .909, .9, .979, .977, .775, .735, and .402, respectively. Two items constituting the seventh factor were excluded from the scale because the reliability coefficient of this factor was low. To monitor the change, factor analysis was applied again for the remaining items without indicating the factor number. The KMO and the Bartlett Sphericity significant values of the scale (six factors), were found to be .946 and .ooo, respectively, and the total variance was found to be $59.301 \%$. The items were examined by researchers. Those items that were placed in the wrong factor according to item statements, and those greatly resembling each other in terms of the statement, were excluded from the scale. The final number of items in the scale was determined to be 30 and the factor analysis was conducted again after the above mentioned items were excluded. 


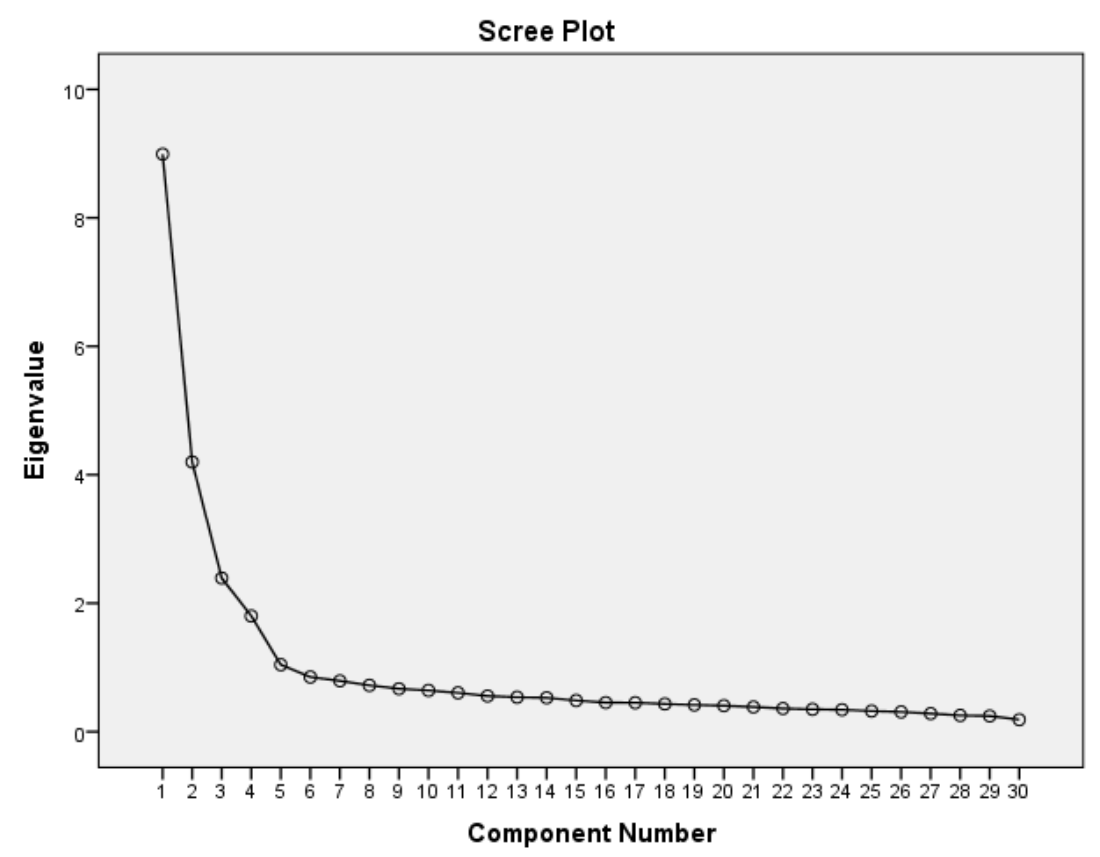

Figure 1. The chart indicating the factor number.

Figure 1 shows that the breakpoint occurred after the $5^{\text {th }}$ factor, and the factor eigenvalue (Table 4) dropped below one after this factor. Accordingly, the scale was found to be a five-factor scale. Table 2 shows that a five-factorial structure explained $61.4 \%$ of the total variance. Accordingly, the five factors identified were: goal setting, help seeking, self-study strategies, managing physical environment, and effort regulation.

Table 4

Factor Eigenvalue and Variance

\begin{tabular}{|c|c|c|c|}
\hline \multirow{2}{*}{ Component } & \multicolumn{3}{|c|}{ Initial eigenvalues } \\
\cline { 2 - 4 } & Total & \% of Variance & Cumulative \% \\
\hline 1 & 8,992 & 29,973 & 29,973 \\
\hline 2 & 4,200 & 14,001 & 43,974 \\
\hline 3 & 2,392 & 7,972 & 51,946 \\
\hline 4 & 1,801 & 6,003 & 57,948 \\
\hline 5 & 1,043 & 3,475 & 61,424 \\
\hline 6 & .851 & 2,837 & 64,261 \\
\hline 7 & .792 & 2,640 & 66,900 \\
\hline 8 & .721 & 2,404 & 69,305 \\
\hline 9 & .669 & 2,228 & 71,533 \\
\hline 10 & .642 & 2,141 & 73,674 \\
\hline.. &.$\cdot$ &.$\cdot$ &.$\cdot$ \\
\hline
\end{tabular}


After the determination of the factor number of the scale, the distribution of items across the factors was determined. The item-total scale correlation, common factor variance values, and factor loading values are shown in Table 5 .

Table 5

Factor Loading and Item Total Correlation Values of the Items

\begin{tabular}{|c|c|c|c|c|c|c|c|}
\hline \multirow[b]{2}{*}{ Item } & \multirow[b]{2}{*}{ 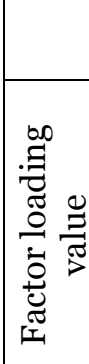 } & \multicolumn{5}{|c|}{$\begin{array}{c}\text { Rotated factor loading } \\
\text { values correlation value }\end{array}$} & \multirow[b]{2}{*}{ 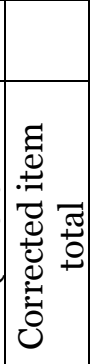 } \\
\hline & & 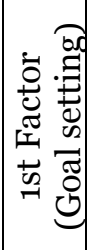 & 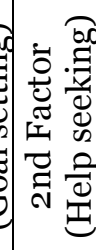 & 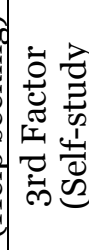 & 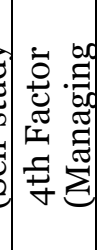 & 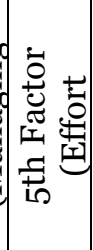 & \\
\hline \#1 I set my study goals daily. & .581 & .768 & & & & & .525 \\
\hline \#2 I set goals for myself while studying. & .582 & .723 & & & & & .523 \\
\hline \#3 I study my lessons in a planned manner. & .586 & .845 & & & & & .529 \\
\hline $\begin{array}{l}\text { \#4 I set goals for myself to arrange my study hours for distance } \\
\text { education lessons. }\end{array}$ & .577 & .794 & & & & & .521 \\
\hline \#5 I do not compromise on the quality of what I do for my lessons. & .604 & .596 & & & & & .544 \\
\hline \#44 I contact someone to discuss my understanding. & .556 & & .567 & & & & .527 \\
\hline $\begin{array}{l}\text { \#45 I participate in social media group discussions regarding } \\
\text { study subjects. }\end{array}$ & .467 & & .704 & & & & .450 \\
\hline $\begin{array}{l}\text { \#47 When I do not understand the distance education course } \\
\text { material, I ask another student for help. }\end{array}$ & .504 & & .777 & & & & .492 \\
\hline $\begin{array}{l}\text { \#48 I contact other students, who I think are successful, on social } \\
\text { media. }\end{array}$ & .491 & & .850 & & & & .484 \\
\hline \#49 I determine what I will ask before receiving help. & .526 & & .691 & & & & .505 \\
\hline $\begin{array}{l}\text { \#50 I find someone who has information about the course content } \\
\text { to consult when I need help. }\end{array}$ & .532 & & .718 & & & & .513 \\
\hline $\begin{array}{l}\# 51 \text { I share my questions about the lessons with other distance } \\
\text { education students on the Internet. }\end{array}$ & .474 & & .803 & & & & .464 \\
\hline $\begin{array}{l}\# 52 \text { I try to talk face-to-face with my classmates in distance } \\
\text { education if necessary. }\end{array}$ & .422 & & .724 & & & & .411 \\
\hline $\begin{array}{l}\text { \#53 I insist on receiving help from someone who has information } \\
\text { about the course content on the Internet. }\end{array}$ & .407 & & .741 & & & & .397 \\
\hline \#21 I think of questions on the subject while reading the material. & .581 & & & .611 & & & .526 \\
\hline $\begin{array}{l}\text { \#22 I draw up a draft of reading material to be able to organize my } \\
\text { thoughts. }\end{array}$ & 632 & & & .780 & & & .577 \\
\hline \#23 I practice by repeating the contents of the material. & .666 & & & .744 & & & .612 \\
\hline $\begin{array}{l}\text { \#24 I review my reading materials and notes and try to find the } \\
\text { most important opinions. }\end{array}$ & 647 & & & .667 & & & .586 \\
\hline $\begin{array}{l}\text { \#25 I create simple schemes, diagrams or tables to organize my } \\
\text { study materials. }\end{array}$ & .588 & & & .740 & & & .532 \\
\hline $\begin{array}{l}\text { \#32 While studying my distance education lessons, I review my } \\
\text { lesson notes and draw up a draft of the important subjects. }\end{array}$ & .587 & & & .661 & & & .540 \\
\hline $\begin{array}{l}\text { \#42 I summarize the subjects to understand what I have learned } \\
\text { from the lessons. }\end{array}$ & .631 & & & .660 & & & .576 \\
\hline
\end{tabular}




\begin{tabular}{|c|c|c|c|c|c|}
\hline $\begin{array}{l}\text { \#43 I evaluate what I understand by pausing at regular intervals } \\
\text { while studying. }\end{array}$ & 647. & .546 & & & .595 \\
\hline \#6 I prefer studying in places where I can concentrate. & .511 & & .805 & & .453 \\
\hline \#7 I choose a comfortable place to study. & .447 & & .803 & & .391 \\
\hline $\begin{array}{l}\text { \#8 I have places where I can study efficiently for my distance } \\
\text { education lessons. }\end{array}$ & .519 & & 615 & & .458 \\
\hline $\begin{array}{l}\text { \# 9 I choose places where nothing distracts me from studying my } \\
\text { distance education lessons. }\end{array}$ & .493 & & .888 & & .435 \\
\hline \#10 I study my lessons in places where I can focus. & .526 & & .870 & & .469 \\
\hline \#11 I have a regular place to study. & .475 & & .529 & & .414 \\
\hline $\begin{array}{l}\# 38 \text { I study the course subjects until finishing them even though I } \\
\text { find the course materials boring. }\end{array}$ & .472. & & & .787 & .415 \\
\hline $\begin{array}{l}\text { \#39 I make an effort to understand the subjects in my distance } \\
\text { education lessons. }\end{array}$ & .564 & & & .763 & .506 \\
\hline
\end{tabular}

The Confirmatory Factor Analysis was conducted using the AMOS program in order to confirm the factorial structure of the scale. The values which should be examined as a result of the Confirmatory Factor Analysis that was stated in a study conducted by Schermelleh-Engel and Moosbrugger (2003) are shown in Table 6.

Table 6

Standard Fit Criteria

\begin{tabular}{|c|c|c|}
\hline Measures & The best values & Acceptable values \\
\hline RMSEA & From 0.00 to 0.05 & From 0.05 to 0.08 \\
\hline SRMR & From 0.00 to 0.05 & From 0.05 to 0.10 \\
\hline GFI & From 0.95 to 1.00 & From 0.90 to 0.95 \\
\hline AGFI & From 0.90 to 1.00 & From 0.85 to 0.90 \\
\hline CFI & From 0.95 to 1.00 & From 0.90 to 0.95 \\
\hline RFI & From 0.90 to 1.00 & From 0.85 to 0.90 \\
\hline
\end{tabular}

The values generated after the Confirmatory Factor Analysis are shown in Table 7. According to a comparison of the values determined by the Confirmatory Factor Analysis with the values in Table 5, it can be stated that the values of Root Mean Square Error of Approximation (RMSEA), goodness-of-fit index (GFI), Adjusted Goodness of Fit Index (AGFI), comparative fit index (CFI) and relative fit index (RFI) showed an acceptable fit, while the value of the Standardized Root Mean Square Residual (SRMR) showed a perfect fit. These data appear to confirm the factorial structure of the self-regulation skills scale. 
Table 7

The Fit Values of Self-regulation Skills Scale

\begin{tabular}{|c|c|}
\hline Measures & Scale values \\
\hline RMSEA & 0.058 \\
\hline SRMR & 0.000 \\
\hline GFI & 0.892 \\
\hline AGFI & 0.873 \\
\hline CFI & 0.914 \\
\hline RFI & 0.885 \\
\hline
\end{tabular}

Factor loadings of the five factors are shown in Figure 2 which were found as a result of the Confirmatory Factor Analysis. As seen in Figure 2, factor loadings for Factor 1 (goal setting) show variation between .67 and .85; for Factor 2 (help seeking) they vary between .59 and .83; for Factor 3 (self-study strategies) they are between .62 and .77; for Factor 4 (managing physical environment) they vary between .53 and .89; and for Factor 5 (effort regulation) they show variations between .70 and .84 . Accordingly, it can be claimed that values of the 30 items in the scale successfully measure the subcomponents of selfregulation; in other words the scale has factorial validity. 


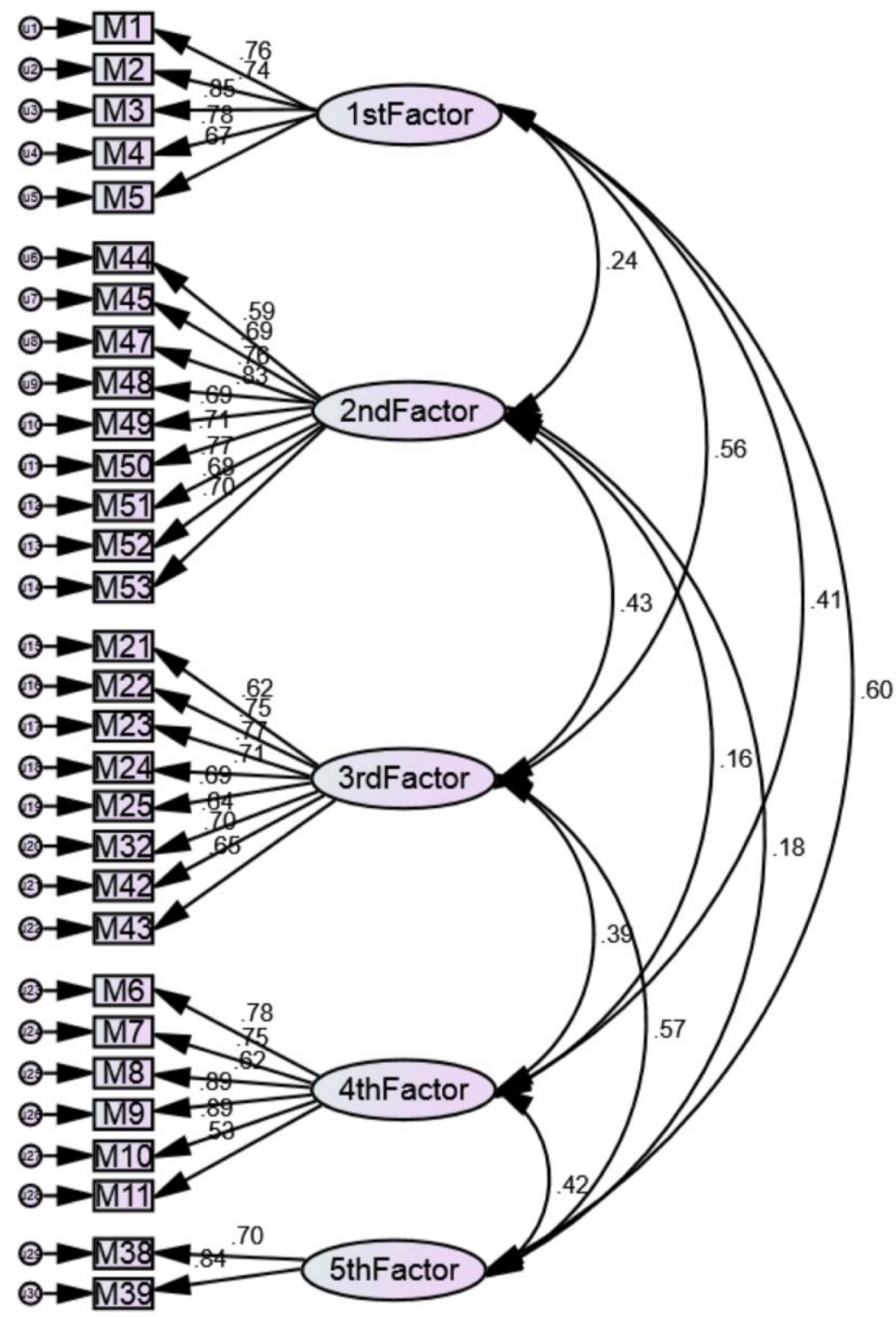

Figure 2. Measurement of self-regulated learning.

\section{Assessing the Reliability of the Draft Scale}

As a result of the reliability analyses conducted on 30 items, the Cronbach's alpha reliability coefficient was calculated to be 0.918 . Buyukozturk (2009) stated that reliability coefficients higher than 0.70 could be regarded as adequate. The fact that the reliability coefficient related to the scale in the present study was found close to 1 indicated that the reliability of this scale was high. The Cronbach's alpha coefficient was calculated to be .868 for Factor 1 (goal setting); .900 for Factor 2 (help seeking); .879 for Factor 3 (self-study strategies); .871 for Factor 4 (managing physical environment); and .735 for Factor 5 (effort regulation). Regarding this, it was clear that the scale also had a high reliability on the basis of the factors.

\section{Discussion}

The aim of this study was to develop a scale assessing the self-regulated learning skills of distance learners who were part of a self-paced distance learning program. Therefore, a 5-point Likert type scale consisting 
of 62 items was prepared according to the answers, on the open-ended questionnaire, given by the distance learners based on the literature review and expert opinions. After obtaining expert opinions, seven items were excluded from the scale. Following the testing of the suitability of data for normal distribution using the descriptive statistical method, the reliability of the scale was evaluated, and the Cronbach's alpha coefficient was found to be .937. The items whose item total correlation was lower than .30 were excluded from the scale because items with a total correlation of .30 or higher differentiate individuals very well. The fact that the differences observed between groups in the desired direction were significant indicates the internal consistency of the test (Buyukozturk, 2009). Accordingly, the independent samples t-test was used to determine the significance (p) of the difference between the item scores of the top $27 \%$ and the bottom $27 \%$. This was done based on the study group to determine the adequacy of each item of the scale in differentiating individuals. Thus, the items whose $\mathrm{p}$ values were higher than 0.05 were excluded from the scale. Subsequently, an Exploratory Factor Analysis was conducted on the remaining items, and the KMO coefficient and the Bartlett Sphericity value were found to be .953 and .0oo, respectively. The fact that the KMO value was found to be higher than .60 and that the Bartlett value was significant indicated that the data were suitable for factor analysis (Guadagnoli \& Velicer, 1988). As a result of the Varimax rotation, the items were divided into seven factors, and the total variance was found to be $58.204 \%$. Since the variance ratio ranging from $40 \%$ to $60 \%$ is regarded as ideal (Scherer, 1988), it can be stated that the variance quantity obtained in the present study was at an ideal level. Previous studies show that 0.40 can be accepted as the bottom cut-off point for the formation of the factor pattern (Ferguson \& Takane, 1989). Moreover, the lower bound of item factor loadings was 0.40, and the difference between the two factor loadings of the same item was .10 at a minimum. The items which did not comply with this criterion were excluded from the scale; the final structure of the scale included five factors and 30 items.

The Confirmatory Factor Analysis was used to test how well the measured variables represent the number of constructs that were obtained through the use of Exploratory Factor Analysis. The Confirmatory Factor Analysis determines whether a structure that was defined and limited before is confirmed as a model, or not (Cokluk, Sekercioglu, \& Buyukozturk, 2010). Following the Confirmatory Factor Analysis, the comparison of the values that Schermelleh-Engel and Moosbrugger (2003) suggested and the values obtained from the scale, showed that the factor structure of self-regulated learning skills scale was confirmed.

Five factors including goal setting, help seeking, self-study strategies, managing physical environment, and effort regulation emerged in the scale, which was developed for the distance learners who are engaged in self-study programs (See Appendix). No other scale whose sample group was the same as this scale was found in the literature. Conversely, the comparison of the scale with the scales developed in different sample groups for face-to-face and cohort-based online learning showed similar factors. For example, the factor called goal setting, which implies setting aims and targeting results while studying, was also included in the OSLQ (Barnard et al., 2009). This similarity was observed despite the different sample group of the OSLQ and the fact that it was developed completely for online settings. Another factor in the scale was determined as help seeking. This factor implies that learners seek help from the Internet and social media, friends, and subject experts. Similarly, the same factor was also included in the MSLQ (Pintrich et al., 1991) and OSLQ scales. Another factor in the scale was called self-study strategies. No scale having the same factor was found in previous studies. This factor includes the methods and strategies followed by learners who are studying on their own. Another factor in the scale was called managing physical environment. This factor implies that the distance learners organize their physical study environment. Similarly, it was observed that the MSLQ included a time/study environmental 
management factor, while the OSLQ had an environment structuring factor. Another factor in the scale was called effort regulation. This factor includes the effort made by the distance learners when they have difficulties in studying. A similar factor is also included in the MSLQ scale.

\section{Conclusion}

Self-regulated learning is a fundamental element for lifelong learning and a process in which a learner controls, monitors, and affects his or her own thinking process that requires knowledge and skill (Dabbagh \& Kitsantas, 2012). Self-regulated learning skills are critical for success in self-paced distance learning environments where learners study on their own. Existing scales that measure self-regulation are not appropriate for self-paced learning. Therefore, a scale was developed in this study to fill in the gap in the literature for measuring self-regulation in self-paced learning environments. The validity and reliability analysis showed that this scale is reliable. The scale can be used to determine the self-regulated learning skills of learners who participate in self-paced courses in either online or traditional distance learning environments such as MOOCs, self-study courses, or courses in open universities. Accordingly, it can be used to determine the activities to be developed for the skills of distance learners. By using the scale, teachers and instructional designers can determine the learning strategies that need improvement. Moreover, educators can use results of this scale to modify the curriculum according to learners' selfregulated skills and personalize learning processes. Besides, researchers can explore the relationship between self-regulation and several factors such as social media use, learning outcomes, achievement, or motivation in self-paced learning environments by using the scale developed in this study.

This study has some strengths and limitations. This scale was developed by the involvement of undergraduate learners enrolled in more than 60 departments with a wide range of age groups from 16 to 69. Therefore, research benefited from maximum variation sampling, which increased the representation of self-paced learners $(n=1,279)$. However, the sample of the study is limited to undergraduate students.

For future research direction, the following implications can be considered by teachers, instructional designers, and researchers. First, it is recommended that further studies, which address different variables in different contexts, should be conducted, and that the scale enlarged to involve different factors. For instance, similar research can be carried out in different cultural settings to see if new items or factors are needed to measure self-regulated skills of the learners. Secondly, future research can focus on measuring self-regulated skills in specific, self-paced learning environments. For example, self-paced learning from the perspective of mobile learning can be examined. Finally, based on the factors identified in this study, teachers, and researchers can work on strategies to develop these skills.

\section{Acknowledgements}

This work was supported by the Anadolu University Scientific Research Projects Commission under Grant no: $1505 \mathrm{E} 360$ and $1605 \mathrm{E} 517$. 


\section{References}

Anderson, T., Annand, D., \& Wark, N. (2005). The search for learning community in learner paced distance education: Or, 'Having your cake and eating it, too!' Australasian Journal of Educational Technology, 21(2), 222-241.

Azevedo, R., \& Cromley, J. G. (2004). Does training on self-regulated learning facilitate students' learning with hypermedia? Journal of Educational Psychology, 96(3), 523-535.

Barnard, L., Lan, W. Y., To, Y. M., Paton, V. O., \& Lai, S.-L. (2009). Measuring self-regulation in online and blended learning environments. The Internet and Higher Education, 12(1), 1-6.

Barnard-Brak, L., Lan, W. Y., \& Paton, W. O. (2010). Profiles in self-regulated learning in the online learning environment. International Review of Research in Open and Distance Learning, 11(1), 61-80.

Bergamin, P.B., Werlen, E., Siegenthaler, E., \& Ziska, S. (2012). The relationship between flexible and self-regulated learning in open and distance universities. International Review of Research in Open and Distributed Learning, 13(2), 101-123.

Brown, J. M., Miller, W. R., \& Lawendowski, L. A. (1999). The self-regulation questionnaire. In L. Vande Creek \& T.L. Jackson (Eds.), Innovations in clinical practice: A sourcebook (pp.281-292). Sarasota, FL: Professional Resource Press/Professional Resource Exchange.

Butler, D. L., \& Winne, P. H. (1995). Feedback and self-regulated learning: A theoretical synthesis. Review of Educational Research, 65(3), 245-281.

Buyukozturk, S. (2009). Sosyal bilimler için veri analizi el kitabr [Handbook of data analysis for social sciences]. Ankara: Pegem Akademi.

Clark, L. A., \& Watson, D. (1995). Constructing validity: Basic issues in objective scale development. Psychological Assessment, 7(3), 309.

Cokluk, O., Sekercioglu, G., \& Buyukozturk, S. (2010). Sosyal bilimler için çok değişkenli istatistik [Multivariate statistics for social sciences]. Pegem Akademi: Ankara.

Dabbagh, N., \& Kitsantas, A. (2005). Using web-based pedagogical tools as scaffolds for self-regulated learning. Instructional Science, 33, 513-540.

Dabbagh, N., \& Kitsantas, A. (2009). Exploring how experienced online instructors use integrative learning technologies to support self-regulated learning. International Journal of Technology in Teaching and Learning, 5(2), 154-168.

Dabbagh N., \& Kitsantas, A. (2012). Personal learning environments, social media, and self-regulated learning: A natural formula for connecting formal and informal learning. Internet and Higher Education, 15, 3-8.

Daniel, J. S. (1996). Mega-universities and knowledge media: Technology strategies for higher education. Brighton: Psychology Press. 
edX. (2018). Differences between instructor- and self-paced courses [Blog post]. Retrieved from http://edx.readthedocs.io/projects/edx-guide-for-students/en/latest/SFD self paced.html

Ferguson, F., \& Takane, Y. (1989). Statistical analysis in psychology and education. New-York: McGraw Hill Book Company.

Garrison, R. (2000). Theoretical challenges for distance education in the 21st century: A shift from structural to transactional issues. International Review of Research in Open and Distributed Learning, 1(1), 1-17.

Guadagnoli, E., \& Velicer, W. F. (1988). Relation to sample size to the stability of component patterns. Psychological Bulletin, 103(2), 265.

Hadwin, A. F., Oshige, M., Gres, C. L. Z., \& Winne, P. H. (2010). Innovative ways for using gStudy to orchestrate and research social aspects of self-regulated learning. Computers in Human Behavior, 26(5), 794-805.

Koçdar, S. (2015). Çevrimiçi ortamlarda öğrenenlerin öz-yönetim becerilerinin geliştirilmesinde kullanılan stratejiler ve araçlar [Strategies and tools used for developing self-regulated skills of learners in online environments]. Açıöğretim Uygulamaları ve Araştırmaları Dergisi, 1(1), 39-55.

Kuo, Y. C., Walker, A. E., Schroder, K. E. E., \& Belland, B. R. (2014). Interaction, Internet self-efficacy, and self-regulated learning as predictors of student satisfaction in online education courses. Internet and Higher Education, 20, 35-50.

Lehmann, T., Hähnlein, I., \& Ifenthaler, D. (2014). Cognitive, metacognitive and motivational perspectives on preflection in self-regulated online learning. Computers in Human Behavior, $32,313-323$.

Littlejohn, A., Hood, N., Milligan, C., \& Mustain, P. (2016). Learning in MOOCs: Motivations and selfregulated learning in MOOCs. The Internet and Higher Education, 29, 40-48.

Milligan, C., Littlejohn, A., \& Margaryan, A. (2013). Patterns of engagement in connectivist MOOCs. Journal of Online Learning and Teaching, 9(2), 149.

Moore, M. G., \& Kearsley, G. (2012). Distance education: A systems view of online learning. Belmont, CA: Wadsworth-Cengage Learning.

Naidu, S. (2008). Enabling time, pace, and place independence. In J. M. Spector, M. D. Merill, J. Merrienboer, \& M. P. Driscoll (Eds.), Handbook of research on educational communications and technology (pp.259-268). New York: Lawrence Erlbaum Associates.

Pintrich, P. R. (2000). The role of goal orientation in self-regulated learning. In M. Boekaerts, P. Pintrich, \& M. Zeidner (Eds.), The handbook of self-regulation: Theory, research, and applications (pp. 451-502). San Diego: Academic.

Pintrich, P. R., Smith, D. A., Garcia, T., \& McKeachie W. J. (1991). A manual for the use of the motivated strategies for learning questionnaire (MSLQ, NCRIPTAL-91-B-004). Retrieved from National 
Center for Research to Improve Postsecondary Teaching and Learning. Ann Arbor, University of Michigan website: https://files.eric.ed.gov/fulltext/ED338122.pdf

Scherer, R. F. (1988). Dimensionality of coping: Factor stability using the ways of coping questionnaire. Psychological Report, 62,76-770.

Schermelleh-Engel, K., \& Moosbrugger, H., (2003). Evaluating the fit of structural equation models: Tests of significance and descriptive goodness-of-fit measures. Methods of Psychological Research Online, 8(2), 23-74.

Sekaran, U., \& Bougie, R. (2016). Research methods for business: A skill building approach. Chichester, United Kingdom: John Wiley \& Sons.

Tavsancil, E. (2014). Tutumlarm ölçülmesi ve SPSS ile veri analizi [Measuring attitudes and data analysis with SPSS]. Ankara: Nobel.

Weinstein, C. E., Palmer, D. R., \& Acee, T.W. (2016). LASSI: User's manual learning and study strategies inventory. Clearwater, FL: H\&H Publishing Company, Inc.

Whipp, J. L., \& Chiarelli, S. (2004). Self-regulation in a web-based course: A case study. Educational Technology Research \& Development, 52(4), 5-22.

Wilson, J. (1997). Self-regulated learners and distance education theory [Electronic document]. Retrieved from http://etad.usask.ca/802papers/wilson/wilson.html

Yukselturk, E., \& Bulut, S. (2007). Predictors for student success in an online course. Educational Technology \& Society, 1O(2), 71-83.

Zimmerman, B. J. (2000). Attaining self-regulation: A social cognitive perspective. In M. Boekaerts, P. R. Pintrich, \& Moshe Zeidner (Eds.), Handbook of self-regulation (pp. 13-39). New York: Academic.

Zimmerman, B. J., \& Risemberg R. (1997). Self-regulatory dimensions of academic learning and motivation. In G. D. Phye (Ed.), Handbook of academic Learning: Construction of knowledge (pp. 105-125). San Diego, CA: Academic.

Zimmerman, B. J., \& Schunk, D. H. (1989). Self-regulated learning and academic achievement: Theory, research, and practice. New York: Springer-Verlag. 


\section{Appendix}

\section{Scale Items}

5-Strongly agree

4-Agree

3-Slightly agree

2-Disagree

1-Strongly disagree

\section{Goal setting}

I set my study goals daily.

I set goals for myself while studying.

I study my lessons in a planned manner.

I set goals for myself to arrange my study hours for distance education lessons.

I do not compromise on the quality of what I do for my lessons.

\section{Help seeking}

I contact someone to discuss my understanding.

I participate in social media group discussions regarding study subjects.

When I do not understand the distance education course material, I ask another student for help.

I contact other students, who I think are successful, on social media.

I determine what I will ask before receiving help.

I find someone who has information about the course content to consult when I need help.

I share my questions about the lessons with other distance education students on the Internet.

I try to talk face-to-face with my classmates in distance education if necessary.

I insist on receiving help from someone who has information about the course content on the Internet.

\section{Self-study strategies}

I think of questions on the subject while reading the material.

I draw up a draft of reading material to be able to organize my thoughts.

I practice by repeating the contents of the material.

I review my reading materials and notes and try to find the most important opinions.

I create simple schemes, diagrams or tables to organize my study materials.

While studying my distance education lessons, I review my lesson notes and draw up a draft of the important subjects.

I summarize the subjects to understand what I have learned from the lessons.

I evaluate what I understand by pausing at regular intervals while studying.

\section{Managing physical environment}

I prefer studying in places where I can concentrate.

I choose a comfortable place to study.

I have places where I can study efficiently for my distance education lessons.

I choose places where nothing distracts me from studying my distance education lessons.

I study my lessons in places where I can focus.

I have a regular place to study.

\section{Effort regulation}

I study the course subjects until finishing them even though I find the course materials boring. I make an effort to understand the subjects in my distance education lessons. 
Measuring Self-Regulation in Self-Paced Open and Distance Learning Environments Kocdar, Karadeniz, Bozkurt, and Buyuk

Athabasca

University

(c) (1) 